\title{
Ngudari reribed: internalization of Ki Ageng Suryomentaram's values to increase mindfulness
}

\author{
Juwita Finayanti, Tyas Martika Anggriana
}

Universitas PGRI Madiun, Madiun, Indonesia

tyas.ma@unipma.ac.id

Submitted : 11-11-2020, Revised : 01-05-2021, Accepted : 28-05-2021

\begin{abstract}
Of happiness can arise from mindfulness because mindfulness creates clarity of consciousness, awareness that does not conceptualize and discriminate, awareness and flexible attention, can have an empirical stand against reality, consciously orientates towards the present, awareness and awareness that stable and sustainable. The purpose of this study was to examine the values contained in the teachings of Ki Ageng Suryomentaram to be applied as a counselling technique based on Indonesian culture. This research method uses a qualitative approach with the type of Gadamerian hermeneutics. The results of the research findings show that: (1) Mindfulness in this context helps to make individuals aware that happiness is not only about fulfilled desires but accepting themselves as they are and fostering an appreciation for moments that occur in life. (2) The compatibility between the technique of "ngudari reribed" and mindfulness lies in the goal of achieving a happy life. (3) Identification of the values contained in Ki Ageng Suryomentaram's discourse can be applied in the "ngudari reribed" counselling technique to increase mindfulness. Mindfulness will help a person feel at peace without worrying about the future and meditating on the past.
\end{abstract}

Keywords : Kawruh Jiwa; Mindfulness; Ngudari Reribed

\section{Introduction}

The conditions that everyone wants are healthy and happy. A healthy and happy person is someone who develops a mindful life (Ahmad \& Suyuthi, 2019). Individuals who achieve a mindful state tend to have low levels of stress when they encounter problems in their lives and have good physical, mental, and socio-emotional health (Anna Erpiana \& Fourianalistyawati, 2018). Feeling peaceful living life will make it easier for individuals to do everything.

However, it turns out that each individual will always be faced with problems to complete their developmental tasks. Every individual faces problems in various aspects of his life (Abubakar et al., 2016). The problems experienced by individuals are related to the characteristics of the development task they are doing. During adolescence, a person experiences physical, psychological and social changes that occur simultaneously so that they have the potential to cause problems that can trigger stressful conditions.

Physical changes are characterized by rapid physical growth and the onset of signs of puberty. Psychological changes, one of which is marked by the emergence of an identity crisis. The identity crisis affects various aspects of life which can cause problems (Patvardhan et al., 2015). Meanwhile, social problems arise when individuals want to know their world. This adolescence occurs when individuals enter junior high school to university students. The range of developments that occur simultaneously with the learning process also has the potential to cause individuals to experience problems in the academic field. Meanwhile, for students who are undergoing the transition from late adolescence to early adulthood, potential problems also arise related to life preparation to enter the world of work and marriage (Awaliyah \& Listiyandini, 2017; Savitri \& Listiyandini, 2017; Waskito et al., 2018; Waskito, 2019).

The development period of adults and the elderly also brings about potential problems that can disrupt the balance of individual welfare. In adulthood individuals think about the welfare of their family which tends to make them stressful (Infurna et al., 2020). Adult problems are related to balancing work and family duties. The task of developing work and family demands the individual's ability to manage both well. On the one hand, individuals feel 
tired due to work, but on the other hand, they must be able to take care of their family properly. This condition often creates the potential for role conflict that affects family and coworkers (A Erpiana \& Fourianalistyawati, 2018). In old age, potential problems can be triggered by the individual's unpreparedness in accepting physical, psychological, social, and spiritual changes. Physical weakness, relinquishment of position and authority, the empty nest phenomenon and several uncertain changes have the potential to make the elderly feel stressed and worried that something bad will happen to them. (Dyah \& Fourinalistyawati, 2018). This problematic condition needs to be considered properly so that they can live a balanced life and achieve happiness.

This happiness and balance can be achieved if a person is focused and has a mindfulness about what he is experiencing around him. having mindfulness makes individuals more grateful for what they have (Carpenter et al., 2019; Goldberg et al., 2018). Baer et al. (2008) describes that mindfulness consists of five components of skills, including: 1) observing, which includes the skills to realize or involve oneself with internal and external experiences; 2) describing, refers to making labels using words about internal experiences; 3) acting with awareness, namely giving full attention to the activities that are currently being carried out; 4) nonjudging of inner experience, including non-evaluative or non-judgmental attitudes towards thoughts that exist within oneself; and 5) nonreactivity to inner experience, is the tendency to let thoughts and feelings come and go, without being trapped or carried too deep. Meanwhile, Hasson (2013) distinguishes mindfulness into 2 types, namely formal and informal. Formal mindfulness is concerned with meditation; whereas informal mindfulness brings more to daily activities and when interacting with other people. Mindfulness is a way of living so that individuals are in the present more often. This involves bringing awareness back from the future or the past and to the present. Mindfulness is living in the present, not living in the present.

Mindfulness can be reviewed in various stages of individual development. Savitri \& Listiyandini (2017) said that adolescents who have more complete awareness (mindfulness) and pay full attention to themselves and their daily lives, will be able to regulate the environment, have control over the activities they undertake, use effectively opportunities in the environment, are able to choose, and create a context that is according to their needs and values. In addition, mindfulness also has a positive contribution to other aspects of psychological well-being, namely life goals, self-growth, self-acceptance, independence, positive relationships with others.

Waskito (2019) describes the mindful character of junior high school students, including independence, in the form of the ability to understand, accept, direct, make decisions and realize oneself responsibly so as to achieve happiness and prosperity in life. In the end, junior high school students will be more adaptive and constructive to face every experience of their life. Maharani (2015) explained that in the realm of education, mindfulness practice can also be developed in the context of teacher-student relationships through mindful teaching. Incorporating mindfulness into teacher-student interactions provides the opportunity for teachers to see current experiences with students as a form of long-term relationship in which there is an understanding of children's needs, development of self-regulatory attitudes, and wise and child-oriented decision making.

When a person is in early adulthood, there are four dimensions of trait mindfulness that play a significant role in the dimensions of psychological well-being, including observing, describing, acting with awareness and non-reactivity to inner experience. However, the nonjudging dimension of inner experience does not play a role (A Erpiana \& Fourianalistyawati, 2018). Meanwhile, when entering old age, there are four of the five dimensions of the mindfulness trait that play a significant role in several dimensions of psychological well-being. The dimensions of the mindfulness trait are acting with awareness, describing, non-reactivity, 
and non-judging. Meanwhile, another dimension that does not play a role in observing (Dyah \& Fourinalistyawati, 2018).

Individual self-awareness is influenced by the values that exist in their culture. The ability to interpret an individual's life is influenced by traditions, upbringing patterns and beliefs. Cultural values greatly influence the behaviour and way of thinking of individuals (Sari et al., 2018; Sari \& Bulantika, 2019). One of the teachings in Javanese culture is the teachings of Ki Ageng Suryomentaram. In culture-based counselling, the teachings of $\mathrm{Ki}$ Ageng Suryomentaram have unique values and contain teachings that can make people happy which are in line with the concept of mindfulness. The uniqueness of Ki Ageng Suryomentaram's teachings about the healthy human model is a very useful philosophy of life (Marhamah et al., 2015). Ki Ageng Suryomentaram's teaching itself becomes intellectual property in the form of local wisdom that attempts to formulate one's own philosophy without depending on the repertoire of Western knowledge.

Suryomentaram teaches how individuals manifest their desires and serenity in life with various experiences of their problems. The mind of someone who is focused on realizing karep (desire), will gradually feel various kinds of reribed (problems). Because happiness arises when a wish is achieved, and a feeling of harm arises when a wish is not achieved. Both feelings, namely happiness and hate, are eternal, and will always come and go in human life. For this reason, humans need to examine their own feelings, so that humans are free from slavery to their feel of response and their feel of notes so that they feel peaceful and eternal (Greenhalgh, 2020; Tozzo et al., 2019). There are three things that Karep always wants to achieve, namely semat, drajat and kramat (wealth, honour and power). Without realizing it, someone has created their own reribed so that feelings such as raos getun (disappointed), raos sumelang (worry), iri and meri pambegan (arrogant). Pursuing semat, drajat, kramat coupled with jealousy and arrogance will only harm oneself (Suryomentaram, 1985). Feeling jealous if his "semat, drajat kramat" is defeated or surpassed by others and feels arrogant if his "semat, drajat, kramat" exceeds or overcomes others. For that someone needs to "ngudari reribed" to be able to find true happiness in life.

Previous research on Ki Ageng Suryomentaram's indigenous counselling, where the character of Ki Ageng Suryomentaram's teachings was unique and contained teachings that could make people happy which was in line with the concept of mindfulness. The uniqueness of Ki Ageng Suryomentaram's teachings about the healthy human model is a very useful philosophy of life. Ki Ageng Suryomentaram's teaching itself becomes intellectual property in the form of local wisdom that attempts to formulate one's own philosophy without depending on the repertoire of Western knowledge (Kholik \& Himam, 2015).

Ki Ageng Suryomentaram expressed a discourse with the name kawruh begja or also known as the science of happiness. The Big Indonesian Dictionary defines happiness as a state of being happy and at ease (free from something troublesome). From this definition, it can be understood that happiness is a state and not an object. While happiness is pleasure or peace itself. Happiness is a positive impact of someone who has mindfulness (Waskito et al., 2018). Life satisfaction as a measure of happiness can arise from mindfulness because mindfulness creates clarity of consciousness, awareness that does not conceptualize and discriminate, awareness and flexible attention, an empirical stand against reality, consciously orientates towards the present, awareness, and awareness stable and sustainable.

Through the technique of ngudari reribed it is hoped that it can increase mindfulness. Because in essence kawruh jiwa is a knowledge capable of "nularke begja" (transmitting happiness), so that it creates begja sesarengan and guyup sesarengan (happy together and in harmony together). The descriptions that have been presented are the connection between "kawruh jiwa" and its relevance to mindfulness. The positive values of kawruh jiwa as local wisdom need to be systematically arranged through writing as a balance to oral culture so that 
these values do not fade and are eroded by the progress of the times. Therefore, it is important to study scientifically about the technique of ngudari reribed in Ki Ageng Suryomentaram's teachings to increase mindfulness (gadamerian hermeneutic study).

\section{Method}

The method used in this research is to use qualitative research with the type of Gadamerian Hermeneutics. The proposition that must be used in this research is to interpret the text by taking into account the factors of dialogue, linguistic factors, historicity, and historical prejudice. The researcher had the opportunity to find the values contained in the kawruh jiwa teachings which aimed to develop counselling techniques which were indigenous counselling with a Javanese cultural background.

The data in this study were collected using three techniques, namely observation, interviews, and documentation. The analyst is data used in downloading describe studies textbook on the values Kawruh Jiwa is by using circle or pattern Parts and Whole, the pattern of interpretation in gaining a deeper understanding in their entirety to the text to look at the whole without forgetting the parts are important in the text itself. Parts and Whole are interconnected where Whole will be obtained after seeing important Parts in a text.

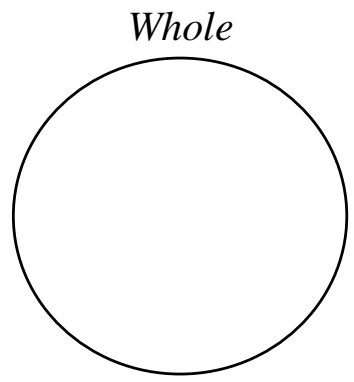

Parts

Gambar 1. Hermeneutic Circle

\section{Results and Discussion}

Kawruh Jiwa is a teaching from Ki Ageng Suryomentaram where kawruh jiwa is knowledge about feel. The characteristic of this kawruh jiwa is to position the feel in the most important thing. By understanding feel, humans can communicate well with other humans, so that someone/individual can understand what someone/other individual feels. Kawruh Jiwa developed by Suryomentaram (1978) is a step for humans to achieve a happy life. Kawruh Jiwa itself is for personal benefit, liberation from worry and suffering.

Mindfulness in this context helps make us aware of how to manage stress, how to get happiness and that luxury is not everything. Baer et al. (2008) describe that when we are going to assess mindfulness, we can see from five components of skills, including 1) observing, which includes the skills to realize or engage with internal and external experiences; 2) describing, refers to making labels using words about internal experiences; 3) acting with awareness, namely giving full attention to the activities that are currently being carried out; 4) nonjudging of inner experience, including non-evaluative or non-judgmental attitudes towards thoughts that exist within oneself; and 5) nonreactivity to inner experience, is the tendency to let thoughts and feelings come and go, without being trapped or carried too deep. Components in assessing mindfulness include the process of observing, interpreting, acting consciously, not subjective to one's experiences and being realistic.

Through the analysis of Gadamerian hermeneutics, this research is carried out in an attempt to reconstruct and reproduce the meaning of the texts contained in Ki Ageng 
Suryomentaram's teaching which has been described in the table below. The skill components covered by mindfulness are then formulated into the values of Kawruh Jiwa. The assessment of the five components of mindfulness-based on the values of kawruh jiwa is depicted in the table below.

Table 1. Components of Mindfulness Skills based on the values of Kawruh Jiwa

No. Mindfulness The Values of Kawruh Jiwa

1 Observing, which includes Nyawang karep (observing the desire) is one of the the skills to realize or engage with internal and external experiences. important points in the Kawruh Jiwa. Because this point is the "intermediate" point for a person in determining the position of his personality.

Nyawang karep is a catching process/ngonangi karep without judging. Someone who is always capable nyawang karep (observe desire) will be able to guide the desire to always follow the natural path and behave right. Otherwise, if someone is unable nyawang karep it will always be swayed by karep (desire) who constantly wants to be satisfied.

2 Describing, refers to making labels using words about internal experiences
Describing her is a condition that has been preceded by the results of one's observations of his desires. With that someone said to himself:

"Lo karep kui nek kalakon yo ora bejo opo, yo mung bungah sedelo, mengko yo banjur susah maneh. Lan nek ora kelakon yo ora cilaka ora opo, mung susah sedelo, mengko yo banjur bungah maneh"

Translation: If the wish is achieved, it will not be happy either, at most, we will be happy for a while, then it will be difficult again. And if it is not done, you will not suffer anything, you will only feel bad for a while, after that you will also be happy again.

At this stage of consciousness, a person can determine the position of his personality. If the awareness stage is successfully implemented, then a person can enter the fourth measure to become a human without characteristics. Where a human without characteristics is someone who has a healthy, happy, prosperous and useful personality for the surrounding environment.

3 Acting with awareness, Ki Ageng Suryomentaram has described it with the namely giving full attention concept of "Saiki (now)", kene (here), ngene (like 
to the activities that are

currently being carried out this), gelem (accepting sincerely) ". It is not

yesterday that we always regret and also not tomorrow that we think about today, which creates excessive anxiety and fear. Ki Ageng

Suryomentaram advised not to go beyond the limit, happiness will come when we don't worry about many things.
$4 \quad$ Non-reactivity to inner experience, is the tendency to let thoughts and feelings come and go, without being trapped or carried too deep.
Ki Ageng Suryomentaram expressed that:

"Pengalaman pait getir punika ingkang dados cobaning gesang. Yen tiyang punika kukawi nandhang cobaning gesang wau kaliyan sabar, tegesipun kuwawi mboten tumindak punapa-punapa ingkang ngrisak masyarakat, tiyang wau lulus anggenipun nampi cobaning gesang, lan awit saking punika tiyang wau tampi piageming gesang. Mila piageming gesang punika raosipun tatag”.

The translation: bitter experience is a life trial if someone can overcome life's trials patiently, meaning that he does not commit actions that damage society, that person passes through or underwent life's trials, and because of that person gets a life certificate and the certificate of life is raos tatag.

A life certificate is a provision for life that comes from the bitter experiences of life that have been perfectly overcome. The bitter experience provides the benefit of being able to appreciate and feel a pleasant feeling.

Ki Ageng Suryomentaram embodies the rules "6 Sa": Sabutuhe, Saperlune, Sacukupe, Sapenake, Samesthine, Sabenere (as needed, as necessary, sufficiently, until it feels good, should, according to the truth). Taught to be simple in thinking and acting. This is related to the feelings that arise in humans, namely interest (happy and difficult). Bungah-susah (happy and sad) are two things that always go back and forth in life. There is no happiness without suffering, and conversely, there is no suffering that does not immediately replace happiness. For that sad and happy as needed. 
Ki Ageng Suryomentaram's teachings are in line with mindfulness. In his discourse, it is known as "kawruh begja" or also known as the science of happiness. Waskito et al. (2018) define happiness (happiness) as the positive impact of someone who has mindfulness. Mindfulness is paying attention in isolation: deliberately, in the moment, and without judgment. This kind of attention fosters awareness, clarity, and a better acceptance of momentof-presence reality (Baer \& Griger, 2013; Kabat-Zinn, 2001). The focus in mindfulness is an individual who focuses on his current life after going through various experiences in his life.

Mindfulness in this context helps to make individuals aware that happiness is not just about fulfilled desires but accepting themselves as they are and fostering an appreciation for the moments that occur in life. Mindfulness and kawruh jiwa have almost the same concept which is characterized by acceptance of what it is by not assessing, accepting, letting go, being aware of it, giving the individual a way to feel happy (Rifani, 2019). As stated by Ki Ageng Suryomentaram in his discourse, "Lo karep kui nek kalakon yo ora bejo opo, yo mung bungah sedelo, mengko yo banjur susah maneh. Lan nek ora kelakon yo ora cilaka ora opo, mung susah sedelo, mengko yo banjur bungah maneh" (desire if achieved not also be happy, most will be happy for a while, then it will be difficult again. And if it does not happen too will not suffer any, just feel bad for a moment, after that too happy again). This explanation implies that the fulfilment of one's desires does not necessarily lead to permanent happiness because feelings of happiness and sadness will always come and go. Happiness will come for a moment, then sadness will come afterwards. Sadness also will not be permanent, because after sadness has passed there will be happiness in the future. Happiness derived someone sete was ngudari reribed his or remove all the problems that come from within him (Finayanti, 2018).

According to $\mathrm{Ki}$ Ageng Suryomentaram, humans often create their own reribed. Problems always come to every individual, without a wave of problems in someone's life, they will not be able to achieve prosperity (Rahmawati \& Utami, 2021). This reribed arises from feelings such as raos getun (disapointed), raos sumelang (worry), jealousy and meri pambegan (arrogant). Negative feelings that arise are caused by the karep (desire) not being fulfilled. Meanwhile, there are three things that karep (desire) always want to manifest, namely semat, drajad and kramat (wealth, honour and power).

Chasing semat, drajat, kramat coupled with jealousy and arrogance will only harm oneself (Suryomentaram, 1985). Feeling jealous if his semat, drajat kramat is defeated or surpassed by other people and feels arrogant if his semat, drajat, kramat exceeds or defeats others. For that one needs to ngudari reribed in order to be able to find true happiness in life. Solving problems and thinking objectively will help individuals to understand individual happiness (Held, 2020; Hendriks \& Bartram, 2019).

The technique of ngudari reribed is based on feel, where ngudari reribed is part of the means of grasping the feel (Kholik \& Himam, 2015). First, what is done for ngudari reribed is with pethukan. This pethukan activity is filled with kandha-takon (tell-ask). Its function is so that someone is able to understand other people, by means of that person expressing his opinion, but not telling others to obey and obey his opinion.

The first Kandha-takon in the ngudari reribed technique is kandha-takon pasinaon raos (learning the feel), which is done here in the form of self-understanding of the catetancatetan (experiences). If you are able to understand the taste yourself, you can proceed to the second stage, namely kandha-takon jawah kawruh, which is self-understanding of what other people feel, also called nyocokaken raos (equating feelings) (Muniroh, 2017). In order for a person's feelings to be felt by others, that person needs to tell his reribed. That way people will know the reribed or the problem that is being felt, termed ngerti, weruh lan krasa dewe (undesrtand, see and perceives itself).

If this kandha-takon is carried out by the counsellor and counselee, then here the counselee shares the problems that are being faced with the counsellor. Counsellors herded feel 
reribed counselees so counselees weruh (knowing), understand (understand), and krasa dewe (perceives itself) that reribed who experienced came from himself always felt getun lan Sumelang (disappointed and worried). If the counselee has made peace with the problem, he will accept himself as it is with the principles of saiki, kene, ngene, gelem (now, here, like this, will).

Through the counselling stages carried out using the ngudari reribed technique, the counselee is helped to identify the problems he is experiencing because he is always feeling disappointed, worried, jealous and arrogant as a result of unfulfilled desires. Through the counselling process, counselees are helped to know, understand and feel for themselves the source of the problems they are experiencing so that they can make peace with the problems they are experiencing. The result of counselling is that the counselee can accept himself as he is with the principles now, here like this and want. The results of counselling are centred on the present and the counselee's desire to be accountable and by prevailing values (Permata et al., 2020).

\section{Conclusions and Suggestions}

Mindfulness helps make us aware of how to manage stress, how to get happiness and that luxury is not everything. Identification of the values contained in $\mathrm{Ki}$ Ageng Suryomentaram's discourse can be applied in a counselling technique where the reribed ngudari technique can be used to increase mindfulness. In the practice of providing counselling services, the values of Kawruh Jiwa can be internalized in the reribed ngudari technique through the pethukan (meeting) stage between the counsellor and the counselee to do kandhatakon (tell-ask). Suggestions for future researchers are to continue to study in-depth and direct the values contained in the teachings of Ki Ageng Suryomentaram as a counselling technique based on Indonesian culture.

\section{References}

Abubakar, A., Van de Vijver, F. J. R., Fischer, R., Hassan, A. S., Gona, J. K., Dzombo, J. T., Bomu, G., Katana, K., \& Newton, C. R. (2016). 'Everyone has a secret they keep close to their hearts': challenges faced by adolescents living with HIV infection at the Kenyan coast. BMC Public Health, 16(1), 1-8.

Ahmad, V. I., \& Suyuthi, A. (2019). Sholat Sebagai Sarana Pelatihan Mindfulness: Jawaban Untuk Tantangan Pendidikan Islam Menghadapi The Age of Complexity. Akademika, 12(1), 105-121.

Awaliyah, A., \& Listiyandini, R. A. (2017). Pengaruh Rasa Kesadaran Terhadap Kesejahteraan Psikologis Pada Mahasiswa. Jurnal Psikogenesis, 5(2), 89-101.

Baer, R. ., Smith, G. ., Lykins, E., Button, D., Krietemeyer, J., Sauer, S., Walsh, E., Duggan, D., \& Williams, J. M. . (2008). Construct Validity of the Five Facet Mindfulness Questionaire in Meditating and Nonmeditating Samples. Assessment, 15(3), 329-342. https://doi.org/10.1177/1073191107313003

Baer, R., \& Griger, P. (2013). Mindfulness: Connecting with your life: A review of the DVD mindfulness for life: An interview with Jon Kabat-Zinn. PsycCRITIQUES, 58(50).

Carpenter, J. K., Conroy, K., Gomez, A. F., Curren, L. C., \& Hofmann, S. G. (2019). The relationship between trait mindfulness and affective symptoms: A meta-analysis of the Five Facet Mindfulness Questionnaire (FFMQ). Clinical Psychology Review, 74, 101785.

Dyah, A. S. P., \& Fourinalistyawati, E. (2018). Peran Trait Mindfulness Terhadap Kesejahteraan Psikologis Pada Lansia. Jurnal Psikologi Ulayat, 5(1), 109-122.

Erpiana, A, \& Fourianalistyawati, E. (2018). No TitlePeran Trait Mindfulness Terhadap 
Psychological Well-Being Pada Masa Dewasa Awal. Psympathic: Jurnal Ilmiah Psikologi, 5(1), 67-82.

Erpiana, Anna, \& Fourianalistyawati, E. (2018). Peran trait mindfulness terhadap psychological well-being pada dewasa awal. Psympathic: Jurnal Ilmiah Psikologi, 5(1), 67-82.

Finayanti, J. (2018). Teknik Ngudari Reribed untuk Mengarahkan Meaning of life. Jurnal Pendidikan: Teori, Penelitian, \& Pengembangan, 3(9), 274-278.

Goldberg, S. B., Tucker, R. P., Greene, P. A., Davidson, R. J., Wampold, B. E., Kearney, D. J., \& Simpson, T. L. (2018). Mindfulness-based interventions for psychiatric disorders: A systematic review and meta-analysis. Clinical Psychology Review, 59, 52-60.

Greenhalgh, W. A. (2020). Mindfulness \& the art of drawing: A creative path to awareness. Leaping Hare Press.

Hasson, G. (2013). Mindfulness. Be Mindful. Live in the Moment. Capstone Publishng Ltd.

Held, B. S. (2020). Epistemic violence in psychological science: Can knowledge of, from, and for the (othered) people solve the problem? Theory \& Psychology, 30(3), 349-370.

Hendriks, M., \& Bartram, D. (2019). Bringing happiness into the study of migration and its consequences: what, why, and how? Journal of Immigrant \& Refugee Studies, 17(3), 279298.

Infurna, F. J., Gerstorf, D., \& Lachman, M. E. (2020). Midlife in the 2020s: Opportunities and challenges. American Psychologist, 75(4), 470.

Kabat-Zinn, J. (2001). Mindfulness Meditation for Everyday Life. Piatkus Books.

Kholik, A., \& Himam, F. (2015). Konsep Psikoterapi Kawruh Jiwa Ki Ageng Suryamentaram. Gadjah Mada Journal of Psychology, 1(2), 120-134.

Maharani, E. A. (2015). Eksplorasi Mindful Teaching Sebagai Strategi Inovatif dalam Pembelajaran Bagi Guru PAUD. Prosiding Seminar Nasional Pendidikan. Inovasi Pembelajaran Untuk Pendidikan Berkemajuan.

Marhamah, Uswatun, \& Murtadlo, A. (2015). Indigenous Konseling ( Studi Pemikiran Kearifan Lokal Ki Ageng Suryomentaram Dalam Kawruh Jiwa ). Jurnal Bimbingan Konseling, 4(2), 100-108.

Muniroh, A. (2017). Kebahagiaan dalam Perspektif Kajian Psikologi Raos. Jurnal Studi Islam, $4(1), 1-9$.

Patvardhan, S. D., Gioia, D. A., \& Hamilton, A. L. (2015). Weathering a meta-level identity crisis: Forging a coherent collective identity for an emerging field. Academy of Management Journal, 58(2), 405-435.

Permata, S., Thahir, A., \& Utami, F. P. (2020). Reality counseling with value judgement techniques to reduce bullying behavior of vocational students. Psychology Research on Education and Social Sciences, 1(2), 83-89.

Rahmawati, R., \& Utami, F. P. (2021). Internalization of Ki Suryomentaram's "Introspection" in Person-Centered Counseling to Build Happiness. PROCEEDING ICTESS (Internasional Conference on Technology, Education and Social Sciences).

Rifani, E. (2019). Integration of Mindfulness and Kawruh Jiwa in Guidance and Counseling Services to Achieve Psychological Well-Being of Students in The Disruption Era. Social, Humanities, and Educational Studies (SHEs): Conference Series, 2(2), 15-23.

Sari, P., \& Bulantika, S. Z. (2019). Konseling indigenous berbasis tata nilai budaya lampung "piil pesenggiri" dalam pembentukan.9(2), 190-199.

Sari, P., Triyono, T., \& Mappiare, A. (2018). Panduan Pertimbangan Nilai Ajaran Nengah Nyappur Etnis Lampung untuk Mereduksi Perilaku Bullying Siswa SMK. Jurnal Pendidikan: Teori, Penelitian, Dan Pengembangan, 3(8), 1095-1099.

Savitri, W. C., \& Listiyandini, R. A. (2017). Mindfulness dan Kesejahteraan Psikologis pada Remaja. Psikohumaniora Jurnal Penelitian Psikologi, 2(1), 43-59. 
Suryomentaram, K. A. (1978). Ilmu Jiwa: Kradamangsa IV. Yayasan Idayu.

Suryomentaram, K. A. (1985). Ajaran-Ajaran Ki Ageng Suryomentaram, jilid 1. PT Inti Idayu Press.

Tozzo, P., Fassina, A., Nespeca, P., Spigarolo, G., \& Caenazzo, L. (2019). Understanding social oocyte freezing in Italy: a scoping survey on university female students' awareness and attitudes. Life Sciences, Society and Policy, 15(1), 1-14.

Waskito, P. (2019). Mindfulness dalam Layanan Bimbingan dan Konseling bagi Peserta Didik Remaja di Sekolah Menengah Pertama. Proceeding. Konvensi Nasional XXI. Asosiasi Bimbingan Dan Konseling Indonesia., 115-121.

Waskito, P., Loekmono, J. T. ., \& Dwikurnaningsih, Y. (2018). Hubungan Antara Mindfulness dengan Kepuasan Hidup Mahasiswa Bimbingan dan Konseling. JKBK Jurnal Kajian Bimbingan Dan Konseling, 3(3), 99-107. 